\title{
A Theory on the Role of Wholesalers in International Trade based on Economies of Scope*
}

\author{
Anders Akerman ${ }^{\dagger}$ \\ First Draft: September 2009 \\ Working Paper Version: January 15, 2010 \\ Research Papers in Economics 2010:1, Stockholm University, Department of Economics
}

\begin{abstract}
Intermediaries and wholesalers play an important role in international trade. This paper develops a model of international trade with heterogenous firms that offers an explanation of the existance of wholesalers. All exporting firms have to pay a fixed cost of establishing a distribution network in the foreign market. However, wholesalers possess a technology different to normal manufacturing firms: they can buy manufacturing goods domestically and sell in foreign markets and handle more than one good. A wholesaler therefore faces an additional fixed cost which is convex and monotonically increasing in the number of goods it ships. The entry of wholesale firms leads to productivity sorting. The most productive firms export on their own, as in the standard model, by paying a fixed cost to do so, while the least productive firms do not export. However, a range of firms with intermediate productivity levels export through international wholesalers. The existance of wholesale firms increase total exports and the number of firms that export. Moreover, a higher fixed cost of exporting leads to (i) a higher share of exported goods that is distributed by wholesalers, and (ii) a higher share of total exports that is distributed by wholesalers. The higher the fixed cost of exporting, the more important is the role of wholesalers since these can spread the fixed cost across more than one good. The wholesale technology therefore exhibits economies of scope. Finally, a larger fixed cost of exporting increases the scope of each wholesaler firm. Empirical evidence from Swedish firms' export patterns supports the main predictions of the model.
\end{abstract}

JEL Classification: D21, F12, F15

Keywords: heterogenous firms, international trade, intermediation, wholesalers

\footnotetext{
*I am grateful for helpful comments and suggestions from Harry Flam and Peter Schott. Financial support from Jan Wallander's and Tom Hedelius' Research Foundation is gratefully acknowledged.

${ }^{\dagger}$ Department of Economics, Stockholm University, email: anders.akerman@ne.su.se.
} 


\section{Introduction}

Recent empirical evidence attributes an important role of wholesalers and intermediaries in international trade. Blum, Claro, and Horstmann (2009a) report that around $35 \%$ of imports into Chile are done through wholesalers. Bernard, Jensen, Redding, and Schott (2009) find that US trading firms exhibit substantial heterogeneity as regards export mode (either firms manage their own exporting activity or export through wholesalers). The literature highlights the fact that the common assumption of firms always being responsible for their own exporting activities does not provide a full picture of firm behaviour in international trade. ${ }^{1}$ Consequently, a growing theoretical literature is currently exploring the issue of intermediation in international trade. This has mainly focused on either matching frictions between buyers and sellers, see Antras and Costinot (2009) or Blum, Claro, and Horstmann (2009b), or on the presence of networks in international trade, see Rauch and Watson (2004) or Petropoulou (2007). ${ }^{2}$

This paper tells a rather different story about why wholesalers exist in international trade. Here, wholesalers are vehicles that are able to pool the fixed cost of exporting across more than one good. I utilise a standard model of international trade with firm heterogeneity and introduce a sector of wholesalers that do not produce themselves but instead buy goods in their local market and export these goods to foreign markets. They only have to incur the fixed cost of establishing a "beachhead" in a foreign market once (regardless of how many goods they export), but face a convexly increasing fixed cost in expanding the set of goods they handle: the fixed cost of their distribution network increases in the range of goods that they export. Wholesalers are assumed to be homogenous in the model since I am mostly interested in how aggregate trade flows and producers of goods respond to the possibility of exporting through wholesalers rather than managing their own distribution networks.

The paper defines the general equilibrium of a small economy that faces a fixed demand from the "rest of the world", a large foreign economy to which firms can export. The model generates a number of predictions to how exporting is conducted in the presence of intermediation. First, producers sort according to productivity in determining their mode of exporting. The most productive firms continue to handle their own exporting atcivities and incur the fixed cost associated with this as in the standard model. However, some firms that were almost productive enough to export on their own in a standard model now choose to do so but through wholesalers instead. The least productive firms do not export through any of the two modes. Second, the size of the foreign market does not matter, instead the size of the fixed cost of exporting drives the dynamics with regard to export mode. A higher fixed cost is associated with a larger importance of wholesalers: a larger share of aggregate exports are now intermediated rather than exported

\footnotetext{
${ }^{1}$ For further empirical evidence, see also Basker and Van (2008a) and Basker and Van (2008b).

${ }^{2}$ Regarding the previous literature, Petropoulou (2007) contains some elements similar to mine but focus rather on explaining the existance of intermediaries through matching frictions. The paper contains convex costs to expanding a network which my model also has, but operates in an environment of homogenous firms. The mechanisms in that paper compared to the model presented here are therefore different.
} 
directly by the producing firm. Moreover, a larger number of firms choose to export through wholesalers rather than managing their own distribution systems when fixed costs of exporting are high. Finally, a larger fixed cost is associated with each wholesaler handling more goods (having a larger scope).

The core mechanism at work in the model is the following: Wholesalers manage to spread the fixed cost of exporting across more than one good, but to cover the fixed cost, they need to charge a markup between the procurement price of the good and what it charges the final consumer in the foreign country. This markup that wholesalers charge causes productivity sorting as regards export mode: the most productive firms choose to incur their own fixed cost of exporting since their operating profit is large enough. However, some goods, which cannot be profitably exported by the producer itself, can be exported at a lower fixed cost per good by wholesalers since these export several goods but only have to make one investment in the fixed cost. This means that the wholesale technology exhibits economies of scope. When fixed costs are larger, wholesalers become more important since less firms can export on their own. Moreover, wholesalers have to expand and handle more goods to be able to cover the larger fixed cost.

The paper uses Swedish firm level data from 2005 which matches customs data with firms. It is therefore possible to see a firm's sector classification and its trade flows by SITC5 product code and destination. It can therefore be observed what goods are exported by firms listed as "wholesalers" and "manufacturers" where the latter are treated as the producers of goods. The analysis supports the main predictions of the model. Wholesalers export, on average, less of a good than producers. Moreover, wholesalers are more important in the exporting patterns to markets with high fixed costs.

Section 2 develops the model and derives the main results. Section 3 provides an empirical analysis. Section 4 discusses the results in light of other empirical evidence available in the literature and Section 5 concludes.

\section{The Model}

The basic model builds on the structure in Helpman, Melitz, and Yeaple (2004), which adds a sector with constant returns to Melitz (2003).

\subsection{Basics}

The model depicts a small economy ("Home") with a primary production factor labour, $L$, which is used in all sectors. It faces a constant demand from the rest of the world (here denoted as "Foreign"). The A-sector (agriculture) is a Walrasian, homogenous-goods sector with costless trade. The M-sector (manufactures) is characterized by increasing returns, DixitStiglitz monopolistic competition and iceberg trade costs. M-sector firms face constant marginal production costs and three types of fixed costs. The first fixed cost, $F_{E}$, is the standard Dixit- 
Stiglitz cost of developing a new variety. The second and third fixed costs are "beachhead" costs reflecting the one-time expense of introducing a new variety into a market.

There is heterogeneity with respect to firms' productivity, $\varphi$. Each Dixit-Stiglitz firm/variety is therefore associated with a particular labour output coefficient - denoted as $\varphi_{i}$ for firm $i$. After sinking $F_{E}$ units of labour in the product innovation process, the firm is randomly assigned an " $\varphi_{i}$ " from a probability distribution $G(\varphi)$.

The analysis exclusively focuses on steady-state equilibria and intertemporal discounting is ignored; the present value of firms is kept finite by assuming that firms face a constant Poisson hazard rate $\delta$ of forced exit.

Consumers in each nation have two-tier utility functions with the upper tier (Cobb-Douglas) determining the consumer's division of expenditure among the sectors and the second tier (CES) dictating the consumer's preferences over the various differentiated varieties within the M-sector.

All individuals in Home have the utility function

$$
U=C_{M}^{\mu} C_{A}^{1-\mu}
$$

where $\mu \in(0,1)$, and $C_{A}$ is the consumption of the homogenous good. Manufactures enter the utility function through the index $C_{M}$, defined by

$$
C_{M}=\left[\int_{0}^{N} c_{i}^{(\sigma-1) / \sigma} d i\right]^{\sigma /(\sigma-1)}
$$

$N$ being the mass of varieties consumed, $c_{i}$ the amount of variety $i$ consumed and $\sigma>1$ the elasticity of substitution.

Each consumer spends a share $\mu$ of his income on manufactures, and demand for a variety $i$ is therefore

$$
x_{i}=\frac{p_{i}^{-\sigma}}{P_{j}^{1-\sigma}} \mu Y
$$

where $p_{i}$ is the consumer price of variety $i, Y$ is income, and $P \equiv\left(\int_{0}^{N} p_{i}^{1-\sigma} d i\right)^{\frac{1}{1-\sigma}}$ the price index of manufacturing goods.

The unit factor requirement of the homogeneous good is one unit of labour. This good is freely traded and since it is chosen as the numeraire

$$
p_{A}=w=1
$$

$w$ being the nominal wage of workers.

Neglecting the role of wholesalers for the moment, shipping the manufactured good involves a frictional trade cost of the "iceberg" form: for one unit of a good from Home to arrive in the Foreign country (denoted by " $F$ "), $\tau>1$ units must be shipped. It is assumed that trade costs are equal in both directions. Profit maximisation by a manufacturing firm $i$ located in Home 
but exporting to the Foreign country leads to the following consumer price in Foreign:

$$
p_{i}^{F}=\frac{\sigma}{\sigma-1} \tau \varphi_{i}^{-1}
$$

Manufacturing firms draw their marginal productivity, $\varphi$, from the probability distribution $G(\varphi)$ after having sunk $F_{E}$ units of labour to develop a new variety. Having learned their productivity, firms decide on entry in the domestic and foreign market, respectively. Firms will enter a market as long as the operating profit in this market is sufficiently large to cover the beachhead (market entry) cost associated with the market. Because of the constant mark-up pricing, it is easily shown that operating profits equal sales divided by $\sigma$. The critical "cut-off" levels of the marginal costs (for the operating profit to be as large as the discounted fixed cost of entry) are given by:

$$
\begin{gathered}
\varphi_{D}^{\sigma-1} B=F_{D}, \\
\varphi_{X}^{\sigma-1} \phi B^{F}=F_{X}
\end{gathered}
$$

where

$$
B \equiv \frac{\mu L}{\left(M_{M} \int_{\varphi_{D}}^{\infty} \varphi^{\sigma-1} d G(\varphi)+M_{X}^{M, F} \phi\left(P_{X}^{F}\right)^{1-\sigma}\right)}
$$

and $F_{D} \equiv \delta \sigma \widetilde{F}_{D}, F_{X} \equiv \delta \sigma \widetilde{F}_{X}$, and $\phi \equiv \tau^{1-\sigma} \in[0,1]$ represents trade freeness. $B$ and $B^{F}$ are the "per firm" demand of the Home market and the Foreign market, respectively. The small economy assumption fixes the size of $B^{F}$ as well as the mass of Foreign manufacturing firms catering to the Home market, $M_{X}^{M, F}$ at the average price $P_{X}^{F}$.

Lemma 1: In a world without wholesalers, only firms with a marginal productivity above $\varphi_{X}$ choose to export, firms with a productivity between $\varphi_{D}$ and $\varphi_{X}$ serve the domestic market and firms with a marginal productivity below $\varphi_{D}$ exit immediately.

\subsection{Introducing wholesalers}

\subsubsection{Assumptions}

The third sector, which is the novel feature of my model, is the wholesale sector (denoted by " $W$ "). The wholesale technology gives a wholesaler firm $j$ the ability to source a range of goods ( " $n_{j}^{W}$ ") and ship these to the Foreign country. The sector is homogenous with free entry and firms are indexed by " $j$ ". A wholesaler faces the same cost as manufacturing firms to establish a retail channel in the foreign country, $F_{X}$, but has the technology to export several goods. 
Since operations become more costly the more goods a firm handles, it also faces a per-period fixed cost that is monotonically and convexly increasing in the range of goods it handles:

$$
s_{j}^{W}=\frac{\left(n_{j}^{W}\right)^{\gamma}}{\gamma}
$$

where $\gamma>1$ and $n_{j}^{W}$ is the number of domestic manufacturing goods the wholesale firm $j$ is handling. Its total fixed cost is therefore $F_{X}+s_{j}^{W}$.

The marginal cost of the wholesaler is, first, the iceberg trade cost, $\tau$, and, second, the procurement price of the domestic manufacturing good. It can be shown that the price that the wholesaler pays the manufacturing firm for its product is simply $p_{i}$, which is a constant markup over the marginal cost of the manufacturing firm (the same cost that producers charge local consumers in the Home country). This is also the result of the fact that producers that sell in the Home country cannot discriminate between final consumers and wholesalers. The total marginal cost of wholesaler firm $j$ sourcing from manufacturing firm $i$ will therefore be:

$$
\begin{aligned}
M C_{i j} & =\tau p_{i} \\
& =\tau \frac{\sigma}{\sigma-1} \varphi_{i}^{-1} .
\end{aligned}
$$

The wholesaler is assumed to get the exclusive right to sell the manufacturing good in the foreign market (thereby excluding the possibility that more than one wholesaler sell the same manufacturing good) and faces the demand $B^{F} p_{i j}^{-\sigma}$ where $p_{i j}$ is the price that wholesale firm $j$ charges for manufacturing good $i$. It will therefore charge the standard CES markup over its marginal cost, thereby creating a "double markup" over the marginal cost of the manufacturing firm:

$$
\begin{aligned}
p_{i j} & =\frac{\sigma}{\sigma-1} M C_{i j} \\
& =\left(\frac{\sigma}{\sigma-1}\right)^{2} \tau \varphi_{i}^{-1} .
\end{aligned}
$$

Note that it can be shown that a wholesaler will always charge a CES markup of $\frac{\sigma}{\sigma-1}$ to the price that the manufacturing firm charges. Moreover, it can also be shown that the manufacturing firm will charge the wholesale firm exactly the same price as it charges domestic consumers. Therefore, it will always use the same price: $\frac{\sigma}{\sigma-1} \varphi_{i}^{-1}$. A manufacturing firm $i$ that exports through wholesalers will sell $\tau B^{F}\left(\left(\frac{\sigma}{\sigma-1}\right)^{2} \tau \varphi_{i}^{-1}\right)^{-\sigma}$ at its standard price $\frac{\sigma}{\sigma-1} \varphi_{i}^{-1}$. Its operating profits from the sales to the wholesaler will therefore be

$$
B^{F}\left(\tau \varphi_{i}^{-1}\right)^{1-\sigma}\left(\frac{\sigma-1}{\sigma}\right)^{\sigma}
$$

while a manufacturing firm exporting on its own would earn

$$
B^{F}\left(\tau \varphi_{i}^{-1}\right)^{1-\sigma} .
$$




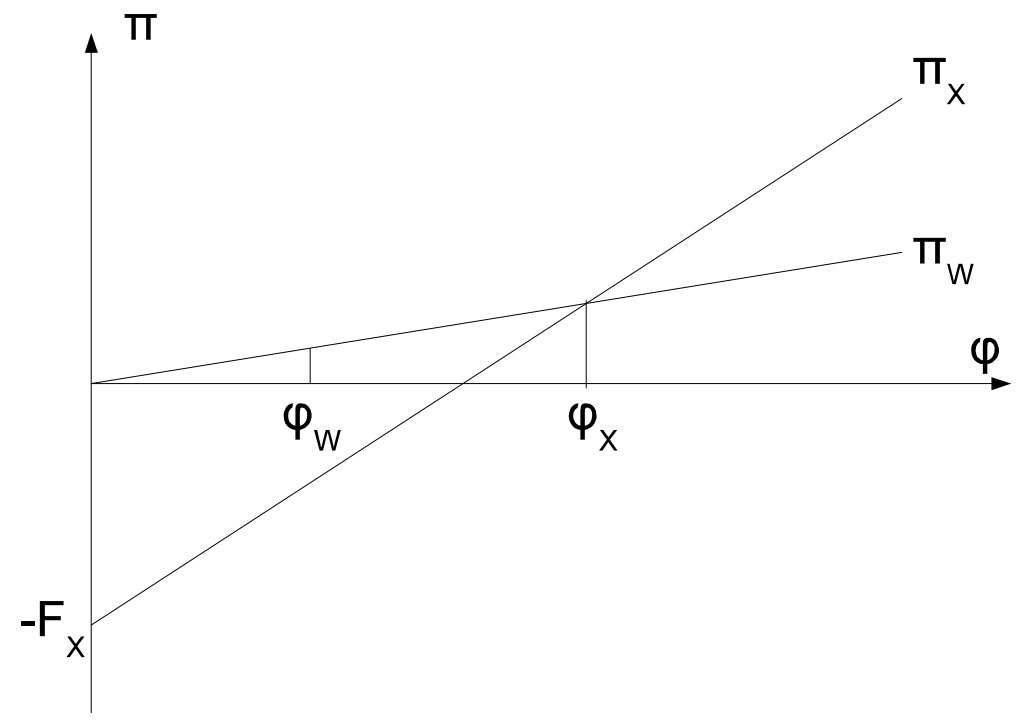

Figure 1: Relative profits for different export modes. $\pi_{X}$ indicates the operating profit of a producer which exports on its own and $\pi_{W}$ indicates the operating profit of a producer exporting through a wholesaler.

Note that

$$
B^{F}\left(\tau \varphi_{i}^{-1}\right)^{1-\sigma}\left(\frac{\sigma-1}{\sigma}\right)^{\sigma}<B^{F}\left(\tau \varphi_{i}^{-1}\right)^{1-\sigma}
$$

meaning that a manufacturing firm would always prefer to export on its own than through a wholesaler, if it only can cover its fixed costs. This is illustrated in figure 1.

Lemma 2 As long as a manufacturing firm's operating profits from exporting cover its fixed cost of exporting, it will always prefer to export on its own to exporting through a wholesaler. This is due to the markup that a wholesaler charges in the foreign country. Export sales per good are lower for wholesalers than for producers exporting on their own.

Proposition 1 The model generates productivity sorting. The most productive firms, $\varphi>$ $\varphi_{X}$, export their products on their own, the second most productive firms, $\varphi \in\left[\varphi_{W}, \varphi_{X}\right)$, export through wholesalers and the least productive firms, $\varphi \in\left[\varphi_{D}, \varphi_{W}\right)$, do not export. That $\varphi_{D}<\varphi_{W}$ has, however, to be assumed (shown later in the paper).

The fixed cost of a wholesaler is

$$
T C_{j}=F_{X}+s_{j}^{W}=F_{X}+\frac{\left(n_{j}^{W}\right)^{\gamma}}{\gamma}
$$

Wholesale firms are homogeneous and I assume that the atomistic manufacturing firms that use wholesalers for the distribution of their goods are "randomly" matched with wholesaler firms 


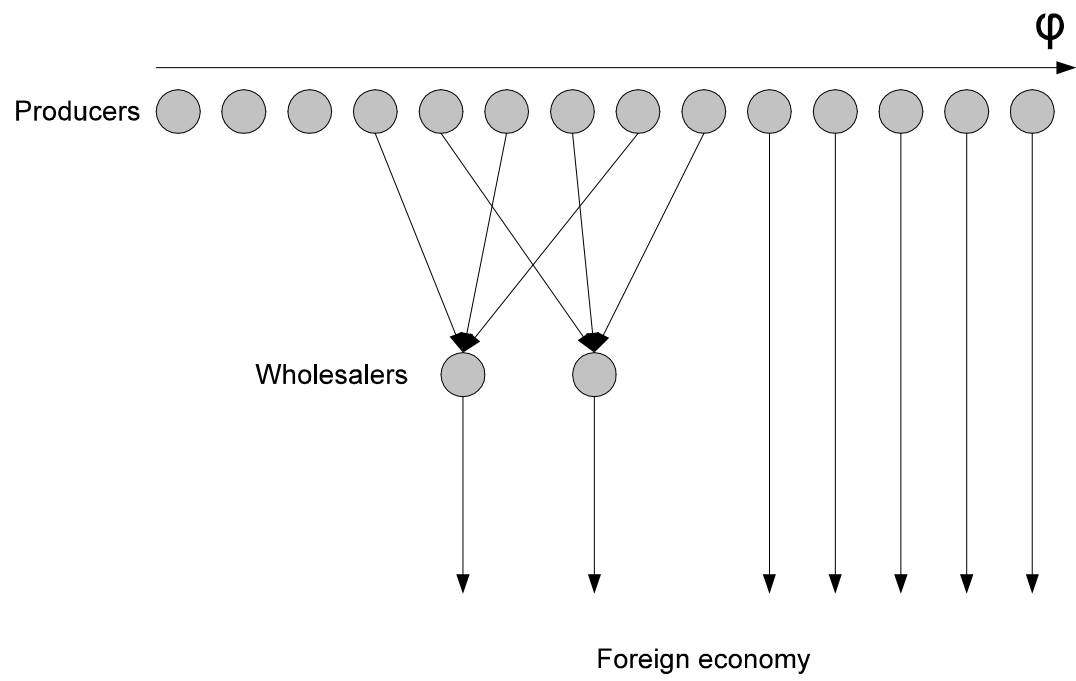

Figure 2: Productivity sorting and export mode.

(see figure 2). This ensures that wholesaler firms in equilibrium will have identical "baskets" of goods that they export. They will have the same range and distribution of productivity among the goods in their baskets. The total number of goods that a wholesaler firm then handles will be equal to the number of manufacturing firms with a productivity between $\varphi_{W}$ and $\varphi_{X}$ $\left(M^{M} \frac{G\left(\varphi_{X}\right)-G\left(\varphi_{W}\right)}{1-G\left(a_{D}\right)}\right)$ where $M^{M}$ is the mass of manufacturing firms, divided by the total mass of wholesale firms, $M^{W}$ :

$$
n_{j}^{W}=\frac{M^{M}}{M^{W}} \frac{G\left(\varphi_{X}\right)-G\left(\varphi_{W}\right)}{1-G\left(\varphi_{D}\right)}
$$

The fixed cost can therefore be written:

$$
\begin{aligned}
T C_{j} & =F_{X}+\frac{\left(n_{j}^{W}\right)^{\gamma}}{\gamma} \\
& =F_{X}+\frac{1}{\gamma}\left(\frac{M^{M}}{M^{W}} \frac{G\left(\varphi_{X}\right)-G\left(\varphi_{W}\right)}{1-G\left(\varphi_{D}\right)}\right)^{\gamma}
\end{aligned}
$$

where $\varphi_{W}$ is the marginal productivity of the least productive manufacturing firm that sells to wholesalers.

Since wholesale firms are homogeneous and manufacturing firms atomistic (infinitely small distributed along the $G(\varphi)$ distribution), it can be assumed that a wholesaler handles goods from the range between $\varphi_{W}$ and $\varphi_{X}$ and that the number of goods it handles is simply this range divided by the total number of wholesale firms, $M^{W}$. It implictly assumes that wholesalers divide the market into equal shares.

Another point is that, as can be shown, the sourcing of wholesalers from manufacturing firms does not change the pricing behaviour of the manufacturing firms. Since the wholesaler 
charges a constant markup over the price of the domestic firms's prices, the manufacturing firms still face a demand schedule with an elasticity of $\sigma$. Manufacturing firms will therefore continue to charge a price with a constant markup over their marginal cost.

\subsubsection{Solving the model with wholesalers}

A wholesaler takes as given the number of other wholesale firms and the number of domestic manufacturing firms. Solving backwards, once the fixed cost is sunk, the pricing mechanism is as described in (10), a constant markup over the marginal cost. Therefore the number of wholesale firms and the range of goods they consume can be determined by two conditions. First, the free entry condition states that the profits of wholesale firms should be zero. Second, the marginal increase in operating profits for a wholesaler firm to expand its set of goods distributed must equal the resulting marginal increase in fixed costs.

The operating profits of a wholesale firm is

$$
\begin{aligned}
n_{j}^{W} \widetilde{\pi}_{j}^{W}\left(\varphi_{W}, \varphi_{X}\right) & =n_{j}^{W} \frac{1}{G\left(\varphi_{X}\right)-G\left(\varphi_{W}\right)} \phi B^{F}\left(\left(\frac{\sigma}{\sigma-1}\right)^{2}\right)^{1-\sigma} \int_{\varphi_{W}}^{\varphi_{X}} \varphi^{\sigma-1} d G(\varphi) \\
& =\frac{M^{M}}{M^{W}} \frac{1}{1-G\left(\varphi_{D}\right)} \phi B^{F}\left(\left(\frac{\sigma}{\sigma-1}\right)^{2}\right)^{1-\sigma} \int_{\varphi_{W}}^{\varphi_{X}} \varphi^{\sigma-1} d G(\varphi)
\end{aligned}
$$

where $\tilde{\pi}_{j}^{W}\left(\varphi_{W}, \varphi_{X}\right)$ is the average operating profit per good handled given the range of productivity in the basket.

Now, the two conditions determining the structure of wholesalers are:

$$
\begin{aligned}
& F_{X}+\frac{\left(n_{j}^{W}\right)^{\gamma}}{\gamma}=n_{j}^{W} \widetilde{\pi}_{j}^{W} \quad \text { (Zero profit condition) } \\
& \frac{\partial}{\partial n_{j}^{W}}\left(F_{X}+\left(\frac{n_{j}^{W}}{\gamma}\right)^{\gamma}\right)=\frac{\partial}{\partial n_{j}^{W}}\left(n_{j}^{W} \widetilde{\pi}_{j}^{W}\right) \quad \text { (Optimal number of goods distributed) }
\end{aligned}
$$

These two conditions determine the number of goods handled $\left(n_{j}^{W}\right)$ and the weighted average of operating profit per good handled

$$
\begin{aligned}
& n_{j}^{W}=F_{X}^{\frac{1}{\gamma}}\left(\frac{\gamma}{\gamma-1}\right)^{\frac{1}{\gamma}} \\
& \tilde{\pi}_{j}^{W}=F_{X}^{\frac{\gamma-1}{\gamma}}\left(\frac{\gamma}{\gamma-1}\right)^{\frac{\gamma-1}{\gamma}} .
\end{aligned}
$$

We see that the fixed cost of exporting, $F_{X}$, is the key variable to understand how the size of wholesaler firms is determined. A larger fixed cost of exporting forces wholesaler firms to expand their scope so that the fixed cost is spread across more goods. The operating profit per good handled must also be larger in equilibrium for wholesaler firms. The variable determining how difficult it is for wholesalers to handle more goods, $\gamma$, also plays a role. The more difficult it is to handle many goods, the greater the effect of the fixed costs on size and average operating profit. 
Proposition 2 The scope of wholesalers increases in the size of the fixed cost of exporting.

Combining (15), and (20), it can be shown that

$$
\frac{1}{G\left(\varphi_{X}\right)-G\left(\varphi_{W}\right)} \phi B^{F}\left(\left(\frac{\sigma}{\sigma-1}\right)^{2}\right)^{1-\sigma} \int_{\varphi_{W}}^{\varphi_{X}} \varphi^{\sigma-1} d G(\varphi)=F_{X}^{\frac{\gamma-1}{\gamma}}\left(\frac{\gamma}{\gamma-1}\right)^{\frac{\gamma-1}{\gamma}} .
$$

where $\varphi_{W}$ is the equilibrium level of the lowest productivity needed for a manufacturing firm to use a wholesaler firm to export. The small economy assumption means that $B^{F}$ is fixed and the export cutoff, $\varphi_{X}$, is determined according to $(7)$ by only $B^{F}, \phi$ and $F_{X}$, which are all exogenous variables (note that $\varphi_{X}$ increases in the fixed cost of exporting and decreases in the foreign market size, $\phi B^{F}$ ). This means that quation (21) yields an implicit and unique solution for $\varphi_{W}$.

Using the equilibrium value $\varphi_{W}^{*}$, it is also possible to find a solution for the number of firms by combining (14) and (19):

$$
\frac{M^{M}}{M^{W}}\left(\frac{G\left(\varphi_{X}\right)-G\left(\varphi_{W}\right)}{1-G\left(\varphi_{D}\right)}\right)=F_{X}^{\frac{1}{\gamma}}\left(\frac{\gamma}{\gamma-1}\right)^{\frac{1}{\gamma}}
$$

Finally, the free entry condition for manufacturing firms says that, in expectation, the expected total profit of entrepreneur must equal the fixed entry cost:

$$
\int_{\varphi_{D}}^{\infty}\left(\varphi^{\sigma-1} B-F_{D}\right) d G(a)+\int_{\varphi_{W}}^{\varphi_{X}}\left(\varphi^{\sigma-1} \phi B^{F}\left(\frac{\sigma-1}{\sigma}\right)^{\sigma}\right) d G(a)+\int_{\varphi_{X}}^{\infty}\left(\varphi^{\sigma-1} \phi B^{F}-F_{X}\right) d G(a)=F_{E} .
$$

The structure described above yields a general equilibrium for the small economy Home.

Proposition 3 The set of equations (6), (7), (8), (21), (22) and (23) yield solutions for the productivity cutoffs $\varphi_{D}, \varphi_{W}, \varphi_{X}$, the mass of wholesale and manufacturing firms, $M^{W}, M^{M}$ and the "per firm" demand $B$.

Proposition 3 characterises the general equilibrium of the small Home economy.

\subsection{Imposing the Pareto distribution}

The equilibrium described in Proposition 2 is somewhat difficult to analyse without any further assumptions about the distribution of productivity, $G(\varphi)$. I therefore impose the scale-free Pareto distribution to yield solutions that are easier to interpret. The scale-free property of the Pareto distribution make general conclusions easier since the exact levels of productivity do not matter as much as relative levels. Moreover, the Pareto distribution has been found to correspond reasonably well with the real distribution of firm productivity, see Axtell (2001) or Luttmer (2007). Now:

$$
G(\varphi)=1-\left(\frac{b}{\varphi}\right)^{k}
$$


where $\frac{k}{\sigma-1} \equiv \beta>1$ and $\varphi \in[b, \infty)$.

To calculate the relative export volumes that occur by firms exporting on their own versus through wholesalers, it can be noted that the export volume of a good through the two export modes is:

$$
\begin{aligned}
V_{X}\left(\varphi_{i}\right) & =\varphi^{\sigma-1} \phi B^{F} \quad \text { (direct exporting) } \\
V_{W}\left(\varphi_{i}\right) & =\left(\frac{\sigma-1}{\sigma}\right)^{\sigma-1} V_{X}\left(\varphi_{i}\right) \quad \text { (wholesale) }
\end{aligned}
$$

The ratio of total export volumes will therefore be

$$
\frac{V_{W}}{V_{X}}=\left(\frac{\sigma-1}{\sigma}\right)^{\sigma-1}\left(\left(\frac{\varphi_{X}}{\varphi_{W}}\right)^{k-(\sigma-1)}-1\right)
$$

which is a direct function of the relative productivity cutoffs $\varphi_{X}$ and $\varphi_{W}$.

The relative mass of firms exporting on their own versus through wholesalers can be written

$$
\frac{M_{W}}{M_{X}}=\left(\frac{\varphi_{X}}{\varphi_{W}}\right)^{k}-1
$$

which is also a direct function of the relative productivity cutoffs.

The equilibrium ratio of productivity cutoffs can be found in (21):

$$
\frac{\left(\frac{\varphi_{X}}{\varphi_{W}}\right)^{k}-1}{\left(\frac{\varphi_{X}}{\varphi_{W}}\right)^{k-(\sigma-1)}-1}=F_{X}^{\frac{1}{\gamma}}\left(\frac{\gamma-1}{\gamma}\right)^{\frac{\gamma-1}{\gamma}} \frac{\beta}{\beta-1}\left(\left(\frac{\sigma}{\sigma-1}\right)^{2}\right)^{1-\sigma}
$$

First, it is interesting to note that neither the variable trade cost, $\phi$, or per firm demand, $B^{F}$, play any role for the export mode. This is due to the fact that for the operating profit, these variables affect wholesalers and direct exporters in identical ways. Second, a higher fixed cost causes the productivity cutoff for exporting to increase. ${ }^{3}$ This, therefore, causes: (i) more firms to export through wholesalers and (ii) the relative export volume that is managed by wholesalers to increase. This result originates in the central dynamic provided by the model: the wholesale industry pools the export fixed costs across goods and can therefore make the fixed cost per

${ }^{3}$ The following is a proof that

$$
\frac{\partial}{\partial x}\left(\frac{x^{a}-1}{x^{b}-1}\right)>0 \quad \text { if } x>1 \text { and } a>b>0 .
$$

First, the condition for the derivative to be positive can be simplified to

$$
x^{a}\left(a-b-a x^{-b}\right)+b>0 .
$$

Now, consider the first two terms of the first product. $x^{a}$ is minimised when $x=1$ and $a-b-a x^{-b}$ is minimised when $x=1$ (recall that $x>1$ ). When $x=1$, the expression on the left hand side is equal to 0 . However, as $x$ increases, both $x^{a}$ and $a-b-a x^{-b}$ increases, meaning that the whole expression on the left hand side will increase. Therefore, the condition holds since $x$ has to be strictly greater than 1 . 
good to be lower. We saw previously that a higher fixed cost also causes wholesale firms to expand the set of goods that they handle. By doing so, the fixed cost per good decreases.

Proposition 4 A higher fixed cost is associated with (i) a higher share of total exports that go through wholesalers and (ii) a larger number of firms exporting through wholesalers relative to exporting themselves. This is due to the fact that wholesalers spread the fixed cost of exporting across more goods.

The wholesaler technology therefore exhibit an increasing returns to scale property with regard to product scope. At low enough numbers of goods handled, an increase in the product scope lower the fixed cost per good, making wholesalers more important as fixed costs increase.

\section{$3 \quad$ Empirical evidence}

\subsection{Main predictions}

The model yields four main falsifiable hypotheses that this section aims to evaluate empirically:

1. Export sales per good are lower for wholesalers than for producers exporting on their own (Lemma 2).

2. A larger share of aggregate export volumes is handled by wholesalers to countries with high fixed costs of entry (Proposition 4).

3. A larger share of the number of exported goods is handled by wholesalers to countries with high fixed costs of entry (Proposition 4).

4. Wholesalers export a wider scope of goods to countries wih high fixed costs of entry (Proposition 2).

In this section, the number of goods and number of products per firm or destination mean the same thing: the number of (SITC5) categories of goods that are exported. The first prediction originates from the fact that goods sold abroad through wholesalers are produced in a less productive way than other export goods and the fact that wholesalers charge an additional markup. The last three predictions, however, are all related to the core mechanism highlighted in the theoretical section. When fixed costs increase, wholesalers' ability to generate economies of scope by spreading the fixed cost of entry across more goods becomes more valuable. Variation in all variables listed is therefore driven by the variation in fixed costs. Measures of fixed costs of entry are always imperfect. The analysis will, however, try to do this in two ways: (i) by viewing market size as a measure of fixed costs, and (ii) backing out a proxy for fixed costs from a gravity model. The next paragraphs outline the theoretical underpinnings of this methodology.

\subsection{Data}

The data on trade will be based on Swedish firm data from the year of 2005 (the most recent year for which such data is available). A firm in this dataset is classified according to its main 
activity and the analysis will utilise firms that are listed as "wholesalers" 4 and firms active in any of the manufacturing sectors. From now on, producers exporting on their own will sometimes be referred to as "manufacturers" since firms that are listed as exporting manufacturers (and not listed as wholesalers) can be assumed to export on their own. Only exporting firms ${ }^{5}$ are used and in 2005 there were 8353 wholesaler firms exporting and 8512 manufacturing firms. The firm level data is from the Swedish firm database called "Företagsdatabasen" and is collected by Statistics Sweden. The trade data is from Customs Sweden and records all trade flows per firm, SITC5 product code and destination country. Only manufacturing SITC5 categories are included in the analysis. For 2005, there are in total 483,809 transactions reported over 2620 SITC5 categories and 194 destination countries.

The average number of product categories that a firm exported was 8.2 for wholesalers and 7.2 for manufacturers. However, manufacturers are much larger and account for $85 \%$ of aggregate export volumes (measured in Swedish currency).

As for market size and the institutional variable used, all data comes from the World Bank's World Development Indicators (WDI) database. Distance measures are from Centre D'Etudes Prospectives et D'Informations Internationales (CEPII).

\subsection{Prediction 1}

This part examines whether sales per good are lower for wholesalers than manufacturers. The theoretical motivation for this is that wholesalers handle goods that are produced with lower productivity than manufacturers and are therefore more expensive. Moreover, wholesalers need to charge an extra markup which exporting manufacturers do not.

As noted, manufacturers account for $85 \%$ of aggregate exports which gives an indication that this prediction holds. However, to account for effects that are specific for products and destination countries, a regression analysis using fixed effects for these variables is applied.

The regression equation that is used will be:

$$
x_{i j l}=\alpha+\beta W_{j}
$$

where $x_{i j l}$ is the logarithm of the exports of product $i$ by firm $j$ to country $l . W_{j}$ is takes the value 1 if the product is sold by a wholesale firm and 0 if it is sold by a manufacturer. Fixed effects for product and destination countries are included. The coefficient $\beta$ therefore measures the difference in export levels per good between wholesalers and manufacturers. To account for characteristics of specific product categories and specific markets, fixed effects are included for product codes and destinations. Otherwise, if wholesalers export within different categories

\footnotetext{
${ }^{4}$ Both "wholesalers" and "retailers" will be called "wholesalers" in the analysis since their activities are probably very similar for the purposes of this paper. The results are, however, robust to using only pure "wholesalers".

${ }^{5}$ Firms with no employees are excluded.
} 
Table 2

\begin{tabular}{|c|c|c|c|c|}
\hline & (1) & (2) & (3) & (4) \\
\hline & \multicolumn{4}{|c|}{ Log(export) } \\
\hline Wholesale dummy & $\begin{array}{l}-0.721^{\star * *} \\
(0.00841)\end{array}$ & $\begin{array}{l}-0.460^{* * *} \\
(0.00850)\end{array}$ & $\begin{array}{l}-0.815^{\star * *} \\
(0.00889)\end{array}$ & $\begin{array}{l}-0.577^{* * *} \\
(0.00944)\end{array}$ \\
\hline Constant & $\begin{array}{c}10.35^{\star \star *} \\
(0.00542)\end{array}$ & $\begin{array}{c}10.24^{* * *} \\
(0.00516)\end{array}$ & $\begin{array}{c}10.39^{* * *} \\
(0.00552)\end{array}$ & $\begin{array}{c}10.29^{* * *} \\
(0.00538)\end{array}$ \\
\hline \multicolumn{5}{|l|}{ Fixed effects } \\
\hline Product & NO & YES & NO & YES \\
\hline Destination & NO & NO & YES & YES \\
\hline Categories & 1 & 2620 & 194 & 81309 \\
\hline Observations & 483809 & 483809 & 483809 & 483809 \\
\hline R-squared & 0.015 & 0.192 & 0.034 & 0.350 \\
\hline
\end{tabular}

than manufacturers, or serve different markets, the coefficient might be biased. Table 2 lists the result.

The regressions indicate that wholesalers, on average, sell between $40 \%$ or $80 \%$ less of a given product to a given country. The negative effect is significant at the $1 \%$ level for all four combinations of fixed effects. It therefore seems as if Prediction 1 holds in the data, wholesalers sell less per good than producers. The effect of including fixed effects is of some magnitude (which means that there is some selection) but not of a very large nature since the results are qualitatively similar.

\subsection{Predictions 2 to 4}

\subsubsection{Market size as a proxy for fixed costs}

Regarding predictions 2 to 4 , the explanatory variable is the fixed cost of entry in all cases. Therefore, these predictions will be examined in the same context in the following text. The theory states that a higher fixed cost increases the importance of the wholesalers' ability of generating economies of scope. Wholesalers are able to spread the fixed cost across several products and are therefore better equipped to export to markets where the fixed cost is high. The main variable for proxying fixed costs will be market size measured by the gross domestic product. Why is this measure correlated with fixed costs? Put simply, it is rather intuitive that the investments required to build a distribution network must be larger in a large country than a small country. The larger the population a firm wants to reach, the more warehouses or the larger warehouses it would want to build in order to cover the whole population. However, a similar story has recently been formalised and empirically tested by Arkolakis (2009). The 
paper provides a microeconomic foundation for a situation where firms endogenously determine how much they invest in the fixed cost. In the model, a marginal unit of investment raises the number of consumers reached by the firm, or the penetration of the market. At the margin, the cost of reaching an additional consumer is lower if there is (i) a large population (since, for example, advertising is more effective if a market is dense) or (ii) the firm's investment level is low (the advertising technology exhibits decreasing returns to scale). The result is that, on average, firms will invest more in the fixed cost to enter larger countries since the returns to advertising spending is larger there.

For the model presented in this paper, this reasoning would be that market size is associated with (i) a higher fixed cost $\left(F_{X}\right)$ and (ii) a larger demand per firm $\left(B^{F}\right)$. The fact that both variables vary with country size would be problematic if it were not for the fact that the model predicts that $B^{F}$ has no impact on the relative levels of wholesaler versus producer sales. Only the fixed cost matters and the results in Arkolakis (2009) can therefore be applied in this context to use market size as a proxy for fixed costs.

This assumption is also supported by Eaton, Kortum, and Kramarz (2005) who find a strong positive relationship between country size and entry cost when calibrating their model ${ }^{6}$ to French firms.

The analysis will employ a cross-country analysis rather than a panel data approach with country fixed effects. The reason for this is that the variation attained when comparing countries is likely to be much more informative for this study than the variation from these variable changing within countries over time. This is because entry and exit patterns of firms take time to reach steady state values and a fixed effect approach will therefore yield results not so much linked to a theory based on general equilibrium analysis but rather the complexities of firm entry and exit which is not the objective of this study.

The analysis, in this section, will therefore focus on market size as a proxy for the equilibrium fixed cost of entry. The variables that the model focuses on are (i) the share of aggregate exports (in value) exported by wholesalers, (ii) the share of the total number of products that are exported by wholesalers and (iii) the number of products that are shipped by each wholesaler.

Figure 3 shows the distribution of the three variables across the markets to which Swedish firms exported in 2005. The share of total exports is calculated by summing the value of all exports to a specific market and then calculating how much of this value was exported by firms listed as wholesalers. The graph shows that, to most markets, the share is rather small, about $10 \%$, but not for all. To some, but very few markets, the share of wholesalers is above $50 \%$. The second graph shows what share of goods that are exported to a specific market that is exported by wholesalers. Since some products are, of course, exported by both wholesalers and producers (each SITC5 product code is an aggregate and therefore includes multiple products within it), the variable listed here is how many products wholesalers export divided by the number of

\footnotetext{
${ }^{6}$ Their model is, of course, different to the present one but they still find a strong positive relationship between fixed entry costs and market size.
} 

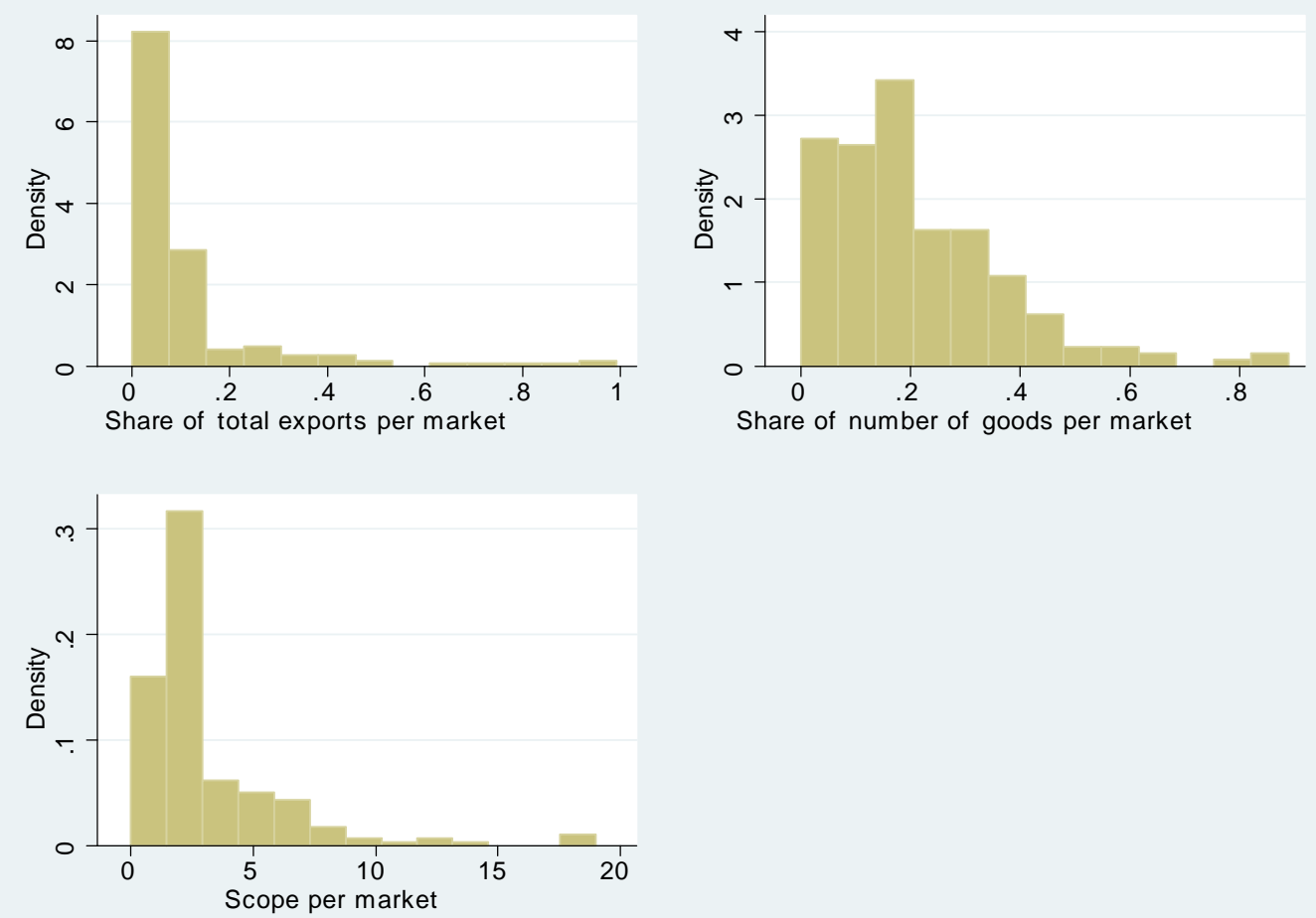

Figure 3: The role of wholesalers in exporting.

products manufacturers export plus how many products wholesalers export. ${ }^{7}$ The relationship is similar to the previous one, although the distribution lies slightly more to the right. This means that to most countries, most products are exported only by the producers. Finally, the third graph describes the scope of wholesalers, the distribution of how many products wholesalers export per market. In most markets, wholesalers export only a few products (less than five), but in some markets more than that.

The empirical methodology will be to, first, plot the relationship between market size and the relevant variables and then, second, examine the relationship in a regression framework.

Figure 4 shows the plots of the three variables versus market size. Some, albeit weak, positive relationships can be observed. A regression analysis is therefore applied as well. The following estimation equation is used:

$$
X_{i}=\alpha+\beta_{1} G D P_{i}+\varepsilon_{i}
$$

where $G D P_{i}$ is the GDP level of the destination country.

Table 3 reports the regression results. All variables are significantly and positively related to GDP in the destination country. That means that wholesalers are more important for

\footnotetext{
${ }^{7}$ Therefore, if wholesalers and producers export exactly the same products, the variable here will have the value 0.5 .
} 

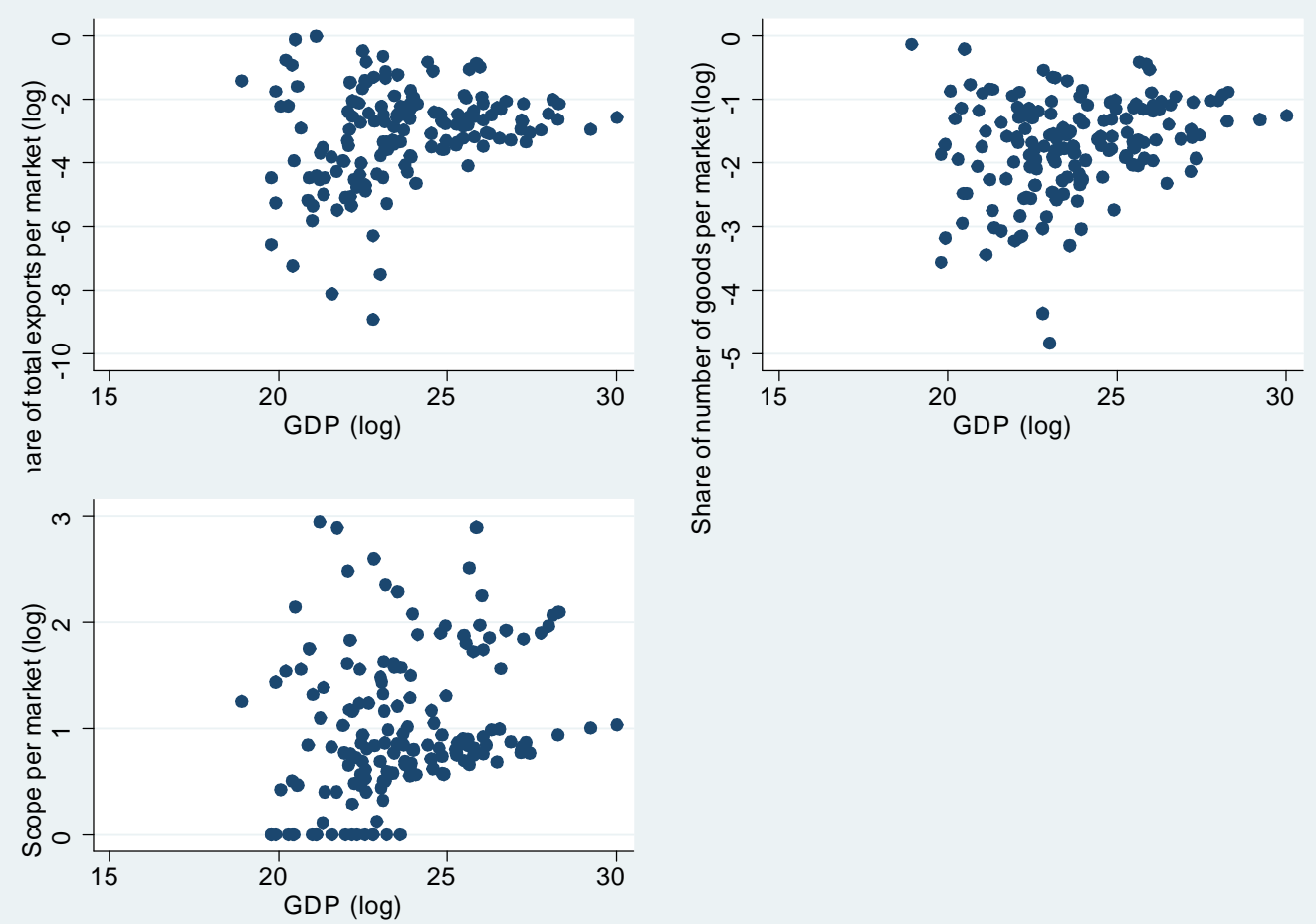

Figure 4: Importance of wholesalers and market size.

Table 3

(1)

(2)

(3)

\begin{tabular}{lccc} 
VARIABLES & $\begin{array}{c}\text { Share of total } \\
\text { exports handled by } \\
\text { wholesalers }\end{array}$ & $\begin{array}{c}\text { Share of number of } \\
\text { products handled } \\
\text { by wholesalers }\end{array}$ & $\begin{array}{c}\text { Number of } \\
\text { products per } \\
\text { wholesaler }\end{array}$ \\
\hline GDP & $0.166^{\star * *}$ & $0.0869^{\star * *}$ & $0.0848^{\star * *}$ \\
& $(0.0526)$ & $(0.0273)$ & $(0.0238)$ \\
Observations & 159 & 159 & 159 \\
R-squared & 0.060 & 0.061 & 0.075
\end{tabular}

Standard errors in parentheses.

${ }^{* * *} p<0.01,{ }^{* *} p<0.05,{ }^{*} p<0.1$. 
exports to large markets. They control a larger share of total exports and they control a larger range of the product scope that is exported. Moreover, they export a wider range of goods in larger markets. If the assumption that fixed costs are larger in larger markets holds, as was argued above, Swedish exporting patterns follow the predictions of the model to the extent that wholesalers are more important in exporting to markets characterised by larger fixed costs.

\subsubsection{Backing out fixed costs from observed export patterns}

If the assumption that market size is a good proxy for fixed costs would not hold, an alternative method would be to use observed export patterns and back out measures of fixed costs. This method is based on the recent literature on how firm heterogeneity impacts the gravity model. Helpman, Melitz, and Rubinstein (2008) show that firm heterogeneity affects the selection of firms and that this has strong impacts on the gravity model, mostly by the presence of trade flows with zero values which were previously ignored. I follow, to some extent, this methodology by using the gravity equation for manufacturing firms (producers) and use the residual from a gravity regression as a proxy inversely related to fixed costs of exporting. The gravity model controls for market size (in the form of GDP and GDP per capita) and variable trade costs (here distance and a measure of institutional quality). What remains can then be argued to be inversely related to the fixed cost and can be used to test the predictions for the aggregate variables in predictions 2 to 4 .

The methodology here will therefore be to, first, use the gravity model to control for market demand and variable costs of exporting as well as a measure of institutional quality: the World Bank's "ease of doing business" ranking system which orders countries according to the quality of business environment (where the first country has the best business environment). ${ }^{8}$ The regression equation is:

$$
X_{i}=\alpha+\beta_{1} G D P_{i}+\beta_{2} \text { distance }_{S W E, i}+\beta_{3} P O P_{i}+\beta_{4} E O D B_{i}+\varepsilon_{i}
$$

where, again, $G D P_{i}$ is the gross domestic product of market $i$, distance $S W E, i$ is the distance from Sweden, $P O P_{i}$ is the population and $E O D B_{i}$ is the proxy for institutional quality. The dependant variable, $X_{i}$, will be used with two cases. First, the measure will be total exports to each country by manufacturing firms (not wholesalers) and, second, it will be the number of (SITC5) products that are exported to each country by manufacturing firms. The reason only manufacturers are included is that equation (7) means that both of these variables (for manufacturers) will increase in market size but decrease in the fixed and variable costs. Note also that by including both GDP and population I implicitly control for GDP per capita. In this way, I control for items that affect the export behaviour through market size and variable trade costs. This leaves a vector of residuals, $\widehat{\varepsilon}_{i}$, which will be interpreted as an implicit measure of

\footnotetext{
${ }^{8}$ The World Bank does not report this ranking for the year of 2005, so instead I take the value from 2008 which is the only year for which this is available. The motivation for doing so is the strong probability that this variables are fairly stable over time across countries.
} 


\section{Table 4}

\begin{tabular}{|c|c|c|c|c|}
\hline \multirow[b]{2}{*}{ VARIABLES } & (1) & (2) & (3) & (4) \\
\hline & $\begin{array}{r}\text { Expc } \\
\text { produce }\end{array}$ & $\begin{array}{l}\text { rts by } \\
\text { s (values) }\end{array}$ & $\begin{array}{r}\text { Expc } \\
\text { producers } \\
\text { SITC5 }\end{array}$ & $\begin{array}{l}\text { rts by } \\
\text { (number of } \\
\text { roducts) }\end{array}$ \\
\hline GDP & $\begin{array}{l}1.076^{* * *} \\
(0.0571)\end{array}$ & $\begin{array}{l}0.942^{\star * *} \\
(0.0803)\end{array}$ & $\begin{array}{l}0.849^{* * *} \\
(0.0428)\end{array}$ & $\begin{array}{l}0.701^{* * *} \\
(0.0571)\end{array}$ \\
\hline Distance & $\begin{array}{c}-0.819^{\star * *} \\
(0.110)\end{array}$ & $\begin{array}{c}-0.797^{\star \star *} \\
(0.106)\end{array}$ & $\begin{array}{l}-0.656^{\star \star *} \\
(0.0821)\end{array}$ & $\begin{array}{l}-0.638^{\star \star *} \\
(0.0756)\end{array}$ \\
\hline Population & $\begin{array}{c}0.0302 \\
(0.0622)\end{array}$ & $\begin{array}{c}0.150^{*} \\
(0.0846)\end{array}$ & $\begin{array}{c}-0.144^{\star \star \star} \\
(0.0465)\end{array}$ & $\begin{array}{l}-0.0203 \\
(0.0602)\end{array}$ \\
\hline Ease of doing business & & $\begin{array}{c}-0.00597^{\star *} \\
(0.00240)\end{array}$ & & $\begin{array}{c}-0.00673^{\star * *} \\
(0.00171)\end{array}$ \\
\hline $\begin{array}{l}\text { Observations } \\
\text { R-squared }\end{array}$ & $\begin{array}{c}174 \\
0.872\end{array}$ & $\begin{array}{c}168 \\
0.886\end{array}$ & $\begin{array}{c}174 \\
0.860\end{array}$ & $\begin{array}{c}168 \\
0.887\end{array}$ \\
\hline
\end{tabular}

Standard errors in parentheses.

${ }^{* * *} p<0.01,{ }^{* *} p<0.05,{ }^{*} p<0.1$.

the fixed cost (a higher $\widehat{\varepsilon}_{i}$ means a lower fixed cost). This is due to the fact that they are the residuals of a regression where both market size (as GDP or GDP per capita) as well as the variable cost (as distance and a measure institutional quality) have been controlled for. What is left could be interpreted as something correlated with the fixed cost of entry; it is backed out by controlling for other observable variables that affect the variables concerned.

Table 4 reports the results from this "first stage" regression. The coefficients support the standard predictions of the gravity model for a setting with heterogeneous firms.

The measure $\widehat{\varepsilon}_{i}$ can then be used in a regression where these three key predictions of the model are tested (predictions 2 to 4 ):

$$
X_{i}=\alpha+\beta_{1} \widehat{\varepsilon}_{i}+\beta_{2} G D P_{i}+\beta_{3} \text { distance }_{S W E, i}+\beta_{4} P O P_{i}+\beta_{5} E O D B_{i}+v_{i} .
$$

where $X_{i}$ will be the three following variables: (i) the share of total exports, in values, that are handled by wholesalers, (ii) the share of products that are sold by wholesalers and (iii) the scope of wholesalers. Note that $\widehat{\varepsilon}_{i}$ is negatively correlated to the fixed cost so the model will predict that all these variables should be negatively correlated with $\widehat{\varepsilon}_{i}$. Table 5 reports the results.

The results in Table 5 are mixed. When the aggregate export volume is used, predictions 2 and 3 are supported (part A in Table 5). When fixed costs are high (low residuals from the first stage regression) wholesalers account for a larger share of the aggregate export volume and for a larger range of goods. Both of these variables have significant and negative coefficients with regard to to the residuals from the first stage regression when export volumes are used 
Table 5

A

\begin{tabular}{|c|c|c|c|c|c|c|}
\hline \multirow[b]{2}{*}{ VARIABLES } & (1a) & $(1 \mathrm{~b})$ & (2a) & (2b) & (3a) & (3b) \\
\hline & $\begin{array}{r}\text { Share } \\
\text { exports h } \\
\text { whole }\end{array}$ & $\begin{array}{l}\text { of total } \\
\text { andled by } \\
\text { salers }\end{array}$ & $\begin{array}{r}\text { Share of } \\
\text { goods } \mathrm{h} \\
\text { whole }\end{array}$ & $\begin{array}{l}\text { number of } \\
\text { andled by } \\
\text { salers }\end{array}$ & $\begin{array}{r}\text { Number of } \\
\text { whole }\end{array}$ & $\begin{array}{l}\text { goods per } \\
\text { saler }\end{array}$ \\
\hline \multicolumn{7}{|c|}{ First stage variable: values of export volume } \\
\hline Residuals from first stage & $\begin{array}{c}-0.564^{\star * *} \\
(0.101)\end{array}$ & $\begin{array}{c}-0.626^{\star \star \star} \\
(0.111)\end{array}$ & $\begin{array}{l}-0.105^{\star} \\
(0.0533)\end{array}$ & $\begin{array}{l}-0.147^{\star \star} \\
(0.0585)\end{array}$ & $\begin{array}{c}0.0734 \\
(0.0447)\end{array}$ & $\begin{array}{c}0.0315 \\
(0.0493)\end{array}$ \\
\hline GDP & $\begin{array}{c}0.0642 \\
(0.0668)\end{array}$ & $\begin{array}{c}0.136 \\
(0.0978)\end{array}$ & $\begin{array}{c}0.0174 \\
(0.0351)\end{array}$ & $\begin{array}{c}0.0145 \\
(0.0516)\end{array}$ & $\begin{array}{c}0.0310 \\
(0.0295)\end{array}$ & $\begin{array}{l}0.00608 \\
(0.0435)\end{array}$ \\
\hline Distance & $\begin{array}{c}-0.586^{* * *} \\
(0.125)\end{array}$ & $\begin{array}{c}-0.550^{\star \star \star} \\
(0.126)\end{array}$ & $\begin{array}{c}-0.439^{\star \star \star} \\
(0.0657)\end{array}$ & $\begin{array}{l}-0.420^{\star \star *} \\
(0.0667)\end{array}$ & $\begin{array}{c}-0.441^{\star \star *} \\
(0.0551)\end{array}$ & $\begin{array}{c}-0.424^{\star \star \star} \\
(0.0562)\end{array}$ \\
\hline Population & $\begin{array}{c}0.0231 \\
(0.0736)\end{array}$ & $\begin{array}{r}-0.0660 \\
(0.105)\end{array}$ & $\begin{array}{c}0.0343 \\
(0.0387)\end{array}$ & $\begin{array}{c}0.0383 \\
(0.0556)\end{array}$ & $\begin{array}{c}0.0241 \\
(0.0325)\end{array}$ & $\begin{array}{c}0.0457 \\
(0.0469)\end{array}$ \\
\hline Ease of doing business & & $\begin{array}{c}0.00229 \\
(0.00296)\end{array}$ & & $\begin{array}{r}-0.000219 \\
(0.00156)\end{array}$ & & $\begin{array}{l}-0.00111 \\
(0.00131)\end{array}$ \\
\hline Observations & 159 & 153 & 159 & 153 & 159 & 153 \\
\hline R-squared & 0.309 & 0.315 & 0.291 & 0.300 & 0.356 & 0.352 \\
\hline
\end{tabular}

B

\begin{tabular}{|c|c|c|c|c|c|c|}
\hline \multirow[b]{2}{*}{ VARIABLES } & (1a) & (1b) & $(2 a)$ & $(2 \mathrm{~b})$ & (3a) & (3b) \\
\hline & \multicolumn{2}{|c|}{$\begin{array}{c}\text { Share of total } \\
\text { exports handled by } \\
\text { wholesalers }\end{array}$} & \multicolumn{2}{|c|}{$\begin{array}{c}\text { Share of number of } \\
\text { goods handled by } \\
\text { wholesalers }\end{array}$} & \multicolumn{2}{|c|}{$\begin{array}{c}\text { Number of goods pe } \\
\text { wholesaler }\end{array}$} \\
\hline \multicolumn{7}{|c|}{ First stage variable: number of export goods } \\
\hline Residuals from first stage & $\begin{array}{l}0.0553 \\
(0.138)\end{array}$ & $\begin{array}{c}0.129 \\
(0.158)\end{array}$ & $\begin{array}{l}-0.166^{\star *} \\
(0.0656)\end{array}$ & $\begin{array}{c}-0.234^{\star \star \star} \\
(0.0747)\end{array}$ & $\begin{array}{c}0.0592 \\
(0.0558)\end{array}$ & $\begin{array}{l}-0.00153 \\
(0.0638)\end{array}$ \\
\hline GDP & $\begin{array}{c}0.0904 \\
(0.0731)\end{array}$ & $\begin{array}{c}0.143 \\
(0.108)\end{array}$ & $\begin{array}{c}0.0177 \\
(0.0348)\end{array}$ & $\begin{array}{c}0.0194 \\
(0.0510)\end{array}$ & $\begin{array}{c}0.0293 \\
(0.0296)\end{array}$ & $\begin{array}{l}0.00565 \\
(0.0436)\end{array}$ \\
\hline Distance & $\begin{array}{c}-0.611^{* * *} \\
(0.137)\end{array}$ & $\begin{array}{c}-0.581^{\star * *} \\
(0.139)\end{array}$ & $\begin{array}{r}-0.439^{* * *} \\
(0.0652)\end{array}$ & $\begin{array}{c}-0.419^{\star \star \star} \\
(0.0659)\end{array}$ & $\begin{array}{c}-0.439^{\star \star *} \\
(0.0554)\end{array}$ & $\begin{array}{c}-0.423^{\star \star *} \\
(0.0563)\end{array}$ \\
\hline Population & $\begin{array}{c}0.0300 \\
(0.0806)\end{array}$ & $\begin{array}{r}-0.0252 \\
(0.116)\end{array}$ & $\begin{array}{c}0.0332 \\
(0.0384)\end{array}$ & $\begin{array}{c}0.0309 \\
(0.0551)\end{array}$ & $\begin{array}{c}0.0241 \\
(0.0326)\end{array}$ & $\begin{array}{c}0.0440 \\
(0.0471)\end{array}$ \\
\hline Ease of doing business & & $\begin{array}{c}0.00140 \\
(0.00326)\end{array}$ & & $\begin{array}{l}-4.10 e-05 \\
(0.00154)\end{array}$ & & $\begin{array}{l}-0.00107 \\
(0.00132)\end{array}$ \\
\hline Observations & 159 & 153 & 159 & 153 & 159 & 153 \\
\hline R-squared & 0.171 & 0.170 & 0.302 & 0.316 & 0.350 & 0.350 \\
\hline
\end{tabular}

Standard errors in parentheses.

${ }^{\star \star \star} p<0.01,{ }^{\star \star} p<0.05,{ }^{*} p<0.1$. 
as the variable in the first stage. However, when the number of goods exported is used, the relationships are less clear and only prediction 3 is supported: a larger range of goods are exported by wholesalers in countries with high fixed costs. The other two variables do not have significant coefficients with regard to the residuals.

How should this be interpreted? It can be argued that export volume is a better variable to use in this case. This is because when measuring the number of goods, many small firms will be included that we know only export very small amounts and enter and exit export markets frequently. In this sense, aggregate export volumes are less susceptible to this type of noise since they are, by construction, weighted averages that give more weight to larger firms.

The analysis therefore concludes that by backing out a proxy of fixed costs which consists of the residual from a gravity model that takes market size and variable trade costs into account, there is some support for the model. Wholesalers are shown to be more important in markets with larger fixed costs, or at least costs that the gravity model does not account for. Wholesalers are more important in both the sense that they control a larger share of the aggregate value of exports and a larger share of the type of goods that are exported.

\section{Conclusion}

The paper presents a model that gives a rationale for the presence of wholesalers and intermediaries in international trade. According to this explanation, wholesalers possess a technology that allows them to use their international distribution network to handle more than one good (although the fixed cost increases in the number of goods they handle), while the producers of these goods (manufacturing firms) can only export their own good. In order to cover the fixed cost of exporting, wholesalers need to charge a markup between the price at which they procure the good and the final price in the foreign country. This markup causes manufacturing firms to export on their own as long as they are productive enough to cover the fixed cost of doing

so. However, if they are not productive enough, they will try to sell their good to the foreign market through a wholesaler's distribution network. This process results in productivity sorting as regards export mode: the most productive firms export on their own while less productive firms export through wholesalers. The least productive firms do not export at all.

Regarding the total shares of exports that are shipped by producers of the goods versus wholesalers' networks as well as the relative numbers of firms, some interesting results are found. Market size and variable "iceberg" trade costs do not matter. Instead, the fixed cost of exporting plays an important role: the higher the fixed cost of exporting, the more of exports take place through wholesalers' distribution networks. This is the case since wholesalers can spread the fixed cost over several goods, as opposed to manufacturing firms, which need to incure one fixed cost for their single good. As fixed costs become more important, firms shift to export through wholesalers (which expand the number of goods they handle) such that they can benefit from lower fixed costs per good exported.

The empirical section supports the main predictions of the model. First, it shows that 
wholesalers export smaller amounts of each product, even when the effect of which particular sector it concerns or which country the good is exported to is controlled for. Second, wholesalers export a larger share of export volumes and the product range to larger markets. The average scope of wholesalers is also larger for exporting to larger markets. If market size (GDP) is a good proxy for fixed costs, as have been found in the previous literature, this supports the prediction that wholesalers are more important for destinations with larger fixed costs. Finally, the paper attempts to back out the fixed cost of entering different destination countries by using the residual from a gravity model as a proxy. This analysis also supports the notion that wholesalers play a larger role in exporting to countries characterised by larger fixed costs of entry. 


\section{References}

Antras, P., and A. Costinot (2009): "Intermediated Trade," Harvard University, mimeograph.

Arkolakis, C. (2009): "Market Access Costs and the New Consumers Margin in International Trade," NBER Working Paper 14214.

Axtell, R. L. (2001): “Zipf Distribution of U.S. Firm Sizes,” Science, 293.

Basker, E., And P. H. VAn (2008a): "Imports ŚRŠ Us: Retail Chains as Platforms for Developing County Imports," University of Missouri, mimeograph.

(2008b): "Walmart as Catalyst to U.S.-China Trade," University of Missouri, mimeograph.

Bernard, A. B., J. B. Jensen, S. Redding, and P. K. Schott (2009): "Wholesalers and Retailers in U.S. Trade," NBER Working Paper 15660.

Blum, B. S., S. Claro, and I. J. Horstmann (2009a): "Facts and Figures on Intermediated Trade," University of Toronto, mimeograph.

- (2009b): "Intermediation and the Nature of Trade Intermediation and the Nature of Trade," University of Toronto, mimeograph.

Eaton, J., S. Kortum, and F. Kramarz (2005): "An Anatomy of International Trade: Evidence from French Firms," 2005 Meeting Papers 197, Society for Economic Dynamics.

Helpman, E., M. J. Melitz, and Y. Rubinstein (2008): "Estimating Trade Flows: Trading Partners and Trading Volumes," Quarterly Journal of Economics, 123.

Helpman, E., M. J. Melitz, and S. R. Yeaple (2004): "Export versus FDI with Heterogeneous Firms," American Economic Review, 94(1), 300-316.

Luttmer, E. G. J. (2007): "Selection, Growth, and the Size Distribution of Firms," Quarterly Journal of Economics, 122(3), 1103-1144.

Melitz, M. J. (2003): "The Impact of Trade on Intra-Industry Reallocations and Aggregate Industry Productivity," Econometrica, 71(6), 1695-1725.

Petropoulou, D. (2007): "Information Costs, Networks and Intermediation in International Trade," University of Oxford, Department of Economics, Discussion Paper 370.

Rauch, J. E., And J. Watson (2004): "Network Intermediaries in International Trade," Journal of Economics and Management Strategy, 13(1), 69-93. 